\title{
Book Reviews/Boekbesprekings
}

Erwin A. Schmidl, Oesterreicher im Burenkiieg 1899-1902; doctoral thesis University of Vienna, 1981, 400 pp., published by the author.

Not only in South Africa and Great Britain there is an increased interest for the second Anglo-Boer War 1899-1902, but also in other countries for whom this war was far away and of limited importance. It is a matter apart to explain the remarkable interest in this colonial war fought long ago. Recently in Vienna the fifth Austrian doctoral thesis regarding this war since World War II has appeared. It is the work of Erwin A. Schmid, a very thorough thesis, based on archival research in Austria, Britain and South Africa, visits to family of veterans in Austria and a tour of the museums and war memorials in South Africa.

The author begins with a sketch of South African history which cannot please all South Africans. I read on p. 21 regarding the Great Trek that the black population was subdued with brutal force; no mention is made of the preceding unprovoked attacks of the Matabeles and Zulus on the Voortrekkers. On p. 23 we find the misconcept that in 1890-99 the foreigners - mainly Britishers - outnumbered the burghers in Transvaal. On $p$. 146 lord Roberts is called as popular with the Boers as with the British soldiers, but I regard the opinion that the Boers hated Roberts even more than Kitchener more acceptable. On $p$. 150 I read the often quoted British reproach that Boer women in concentrations camps painted their sick children green; a proof of their ignorance; the British did not know the green bluegum ointment, house medicine of the Boers, used because of lack of medicine in the ill-supplied camps.

Writing objectively and well-informed about South African history appears to remain difficult. For the rest Schmidl's work is objective and correct in detail.

He continues his book with a survey of consular representatives of the Danube monarchy, much later followed by diplomats in South Africa. More interesting is his description of the volunteers and military attaches from Austria-Hungary in the South African war. A book of this kind contains mainly a collection of more or less complete biographies, most of these of colourful characters. Schmidl has done for the Austrians and Hungarians what Alan $\mathrm{H}$. Winquist did some years ago for the Scandinavians in the war 1899-1902. The characteristics which they ascribe to their fellow countrymen in the war are also to be found in other foreigners in South Africa in 1899-1902. Schmidl states that the immigrants and war volunteers came from all population classes in Austria-Hungary. They are to be distinguished into immigrants who had arrived before the war and were more or less acquainted with the men and circumstances in South Africa, and the freshmen from Europe and America.

He points out the variety of motives to volunteer in the South African war for one of the contesting parties. I am of the opinion that these motives occurred with all foreign volunteers who turned up in this war. Schmidl correctly assumes that only a minority of them was animated by idealism to help the small heroic Boer nation against the overwhelming might of British imperialism. I suppose that unemployment in the republics during the prevailing depression moved many young immigrants to enlist in the British or the Boer army in 1899 because they received free clothing, food and horses and as British recruits a few shillings per day.

Schmidl also refers to the fin-de-siecle feelings with some European intellectuals which drove them to South Africa because they were dissatisfied with European civilization and esteemed the Boers as a simple, morally pure agrarian people. Examples are the Austrian military attache Robert Trimmel ( $p .218$ ), the Austrian count Adalbert von Sternberg (p. 258) and the French colonel Georges de Villebois-Mareuil.

The idealistic pro-Boers however experienced severe disappointment because of the cool reception by the rank and file of the Boers. There were so many selfish adventurers and fortune hunters among the foreign volunteers that the burghers soon mistrusted them. Moreover they despised their lack of knowledge of veld-life.

Another category of foreign volunteers consisted of the black sheep of distinguished European families who had failed in their own country. Among them we find several army officers. 
Schmidl mentions the Austrians and Hungarians Robert Birnbacher, Anton baron von Goldegg, leader of the small Austro-Hungarian corps, Felix baron Lúszensky and Tibor Péchy, nephew of pope Leo XIII. Since 1871 Europe and the USA had not waged a major war and some officers were bored, spent too much money, misbehaved or ran into high debts. Some of them left for the war in South Africa as 'Beurlaubte' to seek adventure and escape their creditors. Many of them expected the Boer government to give them the command of a division and high pay, but they had to serve as common burghers and the Boers ignored their military advice. After their return to Europe some of these black sheep distinguished themselves in World War I, eg Von Goldegg and Birnbacher.

Thanks to the service reports regarding officers in the military archives Schmidl is better informed about the officers than the civilian volunteers among the Austrians and Hungarians. Some of these were journalists, eg Franco Seiner, whose lively book of the war is often quoted by Schmidl. He mentions on p. 298-308 also Austrians and Hungarians as volunteers with the British army in South Africa, namely the officers August J. Meyer and Viktor baron Ramsnerg and private Lájos Vádasz.

Some foreigners fought bravely and lost their lives or health; losses of the foreign brigades were much higher than in the Boer commandos. Other foreigners however behaved like parasites, chaffered and stole - be it partly because the Boers did not feed and clothe them - and belonged to the 'Schlachtenbummler' who followed the fighters to the front but avoided fights and looked for loot. The British press called them mercenaries, although they were not paid, and it is true that many had the mentality of 'Landsknechte'. Schmidl refers to this kind of soldiers in the post-decolonization wars in Africa since 1960 on p. 312-315, and mentions the book 'The wild goose' which describes them. The British press overestimated the role of the foreigners in the Boer ranks or underestimated them as skunking loot-seekers.

A seperate category of foreign volunteers were the personnel of European ambulances who often served the Boer forces excellently. Some of them continued their charitable work during the strenuous guerrilla war. Schmidt mentions the Austrian surgeons Florian Albrecht, Simon Benz and Siegmund Kaufmann.
The last category of foreigners were the military attaches with the British and Boer armies. They were professional, selected officers sent by their general staff to the war in South Africa to report as had become usual in Western armies in the course of the 19th century. Most of them were excellent observers and some did good journalistic work and published good reportages. We know the careers and characters of most of them. Schmidl mentions most of them and of course devotes his attention largely to the Austrian, Robert Trimmel, with the British army. He gives a biography of this intelligent officer.

I may add that Trimmel had the same experiences as other young military attaches after their return from South Africa, namely the Dutchman lieutenant L.J.K. Thomson and the Norwegian captain J. Allum. This war taught them to depreciate parade gymnastics and to recommend accurate shooting-practice, seeking of cover on the soldier's own initiative, avoidance of attacks in closed ranks and quick-firing guns. Their newfangled ideas found little response among elder senior officers who had participated in European wars long ago, such as in France in 1870-71 and the Balkan in 1877-78, and in colonial wars against primitive people. The attaches' extensive reports were provided with comments showing adhesion or doubt because warfare in Europe was thought quite different from war in South Africa. Guerrilla warfare was practically ignored. Lively discussions in meetings and military journals ensued but for few years. Thereafter the much more important Russo-Japanese war in 1904-05 overshadowed the South African war and the reports about this war were shelved in the archives. It is an open question whether and how much European general staffs have learned from the war in South Africa; I fear not much. Only since the last few years historians undig the attaches reports, dust them off and publish them with comments.

Schmidl relates that Trimmel's very extensive report shared the fate of most reports. Despite the personal interest of the emperor and the archduke as commander-in-chief the highest army officers practically ignored Trimmel's remarks and discouraged the continuance of his cordial contact with the British army. Trimmel served bravely as a major in World War I, was distinguished several times and died at the age of 88 in Vienna.

Schmidl does not analyse Trimmel's unpublished report, perhaps because it is too long 
and because Schmidl did not want to add to his thesis of 400 pages. A microfilm of Trimmel's report of towards 1000 pages is in the archive of the South African Defence Force and of the State archive in Pretoria.

Schmidl had written an excellent work and I hope that it will be soon generally available, if possible with a translation in English.

\section{Dr C. de Jong (University of South Africa)}

'Ragtime Soldiers: The Rhodesian experience in the First World War' deur Peter McLaughlin. Books of Zimbabwe, Posbus 1994, Bulawayo, Zimbabwe, 1980 (pp. 159 met foto's, kaarte en register).

Hierdie werk, wat deur $n$ jong akademikus geskryf is, sal aan die verwagtings van hulle teleurstel wat 'n wetenskaplik-verantwoorde militêre-historiese publikasie verwag. Dit was nie die doel wat die outeur beoog het nie. Hy wou, omdat hy getref was deur die mate van onbekendheid in sy land aangaande die deelname van Rhodesië aan die Eerste Wêreldoorlog, daardie leemte op 'n populêre wyse aanvul. Sover afgelei kan word het hy beskikbare argiewe en die dagbladpers van die jare 19141918 met vrug geraadpleeg en verwerk. Waarin hy veral geslaag het, is sy lewendige verhaaltrant wat die leser in sy verbeelding terugvoer na gebeurtenisse wat vandag grotendeels vergeet is, na persoonlike ervarings van deelnemers aan die uitputtingsoorlog in die destydse bosoorlog in Oos-Afrika en die worstelinge in die loopgrawe aan die wesfront in Europa. Dit is 'n boek vol atmosfeer en wisselende stemmingsbeelde, politiek en militêr aan die tuisfront, militêr aan die onderskeie fronte waar Rhodesiers geveg het. Die front in Oos-Afrika, weliswaar ' $n$ vergete front in 1914-1918, maar van die uiterste belang vir toekomstige militëre beplanners en deelnemers aan die Tweede Wëreldoorlog, waaronder - in albei gevalle - van ons eie weerbare Suid-Afrika sowel as Rhodesië het albei as buurlande en gekoppel aan die destydse Britse wêreldryk in die Eerste Wêreldoorlog betrokke geraak in 'n tydperk waarin aldus die skrywer 'n Britse oorlog 'n ryksoorlog was. Suid Rhodesië is deur 'n maatskappy, die British South Africa Company(BSAC) bestuur. Suid Rhodesië se blanke bevolking het, en ons haal weer aan - daarna gestrewe 'to out-British the British' terwyl SuidAfrika vir die eerste maal na 1902 deur die deel- name aan die oorlog op die pad na innerlike verskeurdheid geplaas was. Rhodesië het oor twee verdedigingseenhede, die British South Africa Police (1 150) en die Southern Rhodesia Volunteers (2000) beskik. Hierdie eenhede was nie in alle opsigte slaggereed nie. Die opleiding en samestelling was van 'n twyfelagtige waarde vir deelname aan die gewapende konflik in Europa. Waar die geesdrif hoof opgevlam het en Rhodesiërs tot die stryd wou toetree, het 300 by Britse eenhede aangesluit. Met die uitbreek van die rebellie in Suid-Afrika het 'n verdere 200 vrywilligers in Salisbury, wat in die voetspore van hulle voorgangers wou volg, in militêre diens van Suid-Afrika getree om te help om die Rebellie te onderdruk. Hierdie eenheid, bekend as 1 Rhodesia Regiment, het te Bloemfontein aangekom. Te laat om die Rebellie te help onderdruk is die eenheid te Tempe gestasioneer om daarna oorgeplaas te word na Maitland. Daarna is die Rhodesiërs, aan boord van die Monarch na Walvisbaai verskeep. Hulle aandeel in die veldtog in DSWA is in hoofstuk 2 beskryf. Terug in Kaapstad is die eenheid ontbind. Die lede van 1 RR het ò by Britse eenhede ò by SA eenhede aangesluit. Hulle bestemming was die oorlogsterrein in Wes-Europa.

Hoofstuk 3 (pp. 19-47) bied die leser 'n lewendige oorsig oor dié Rhodesiërs se militêre optrede wat hom in Duits Oos-Afrika afgespeel het tot Februarie 1917. 2 Rhodesia Regiment het vroeg in 1915 op die oorlogsterrein verskyn. In hierdie hoofstuk verkry die leser 'n uitstekende oorsig oor die bosoorlog met al sy probleme, soos dikwels ontoereikende rantsoene, menigvuldige siektes, vervoervraagstukke, klimaatinvloede, vindingrykheid, ontberings e.d.m. Hierdie faktore het 2 RR verswak en verliese laat ly. Elke maand was 150 nuwelinge benodig om die eenheid op die vereiste sterkte te laat bly. Aangesien dit onmoontlik was, het die oorblywendes van 2 RR in April 1917 na Rhodesië teruggekeer $2 R R$ is ontbind en die gewilliges wat nog kon veg is in Suid-Afrikaanse infanterie-eenhede opgeneem of het op eie houtjie by Britse eenhede aangesluit. Op 12.10.1917 het 2 RR, waarvan 'n groot aantal lede in DDA onder genl J.C. Smuts geveg het, se laaste uur geslaan. Dié Rhodesia Native Regiment het die stryd tot die einde voortgesit. een van die redes was dat hulle gewoond geraak het aan tropiese toestande. Hierdie hoofstuk is ryk aan persoonlike indrukke van hulle wat aan hierdie veldtog deelgeneem het. Daar is ook besonderhede in verband met menigvuldige vervoerprobleme en mediese toestande. 2 RR het 2272 hospitaal- en 10626 siektegevalle ge- 